\title{
Upaya peningkatan kemampuan pemecahan masalah matematis siswa MTs melalui model pembelajaran kooperatif tipe STAD
}

\author{
Ade Evi Fatimah* \\ STKIP Al-Maksum Langkat, Stabat, Sumatera Utara, Indonesia, 22811 \\ *Corresponding Author: eviade997@gmail.com
}

\begin{abstract}
The purpose of this study is to improve the mathematical problemsolving ability of students in class VII-1 MTs Islamiyah Medan through the STAD type cooperative learning model. This research is a Class Action Research (CAR). The subjects of this study were 40 students of grade VII-1 MTs Islamiyah Medan. The object in this study is to improve students' mathematical problem-solving abilities through the STAD Type Cooperative learning model on the subject of rectangular flat shapes. This research instrument uses tests of mathematical problem-solving abilities, observation, and interviews. Based on the preliminary results of the interviews conducted with the mathematics teacher, it was obtained that the mathematical problemsolving ability of students in class VII-1 MTs Islamiyah Medan was still not optimal. From the data obtained only $17.5 \%$ of students met the mathematical problem-solving ability criteria. This research was conducted in two cycles by providing treatment using STAD learning. Based on the results of data analysis students' mathematical problem-solving abilities in the first cycle obtained that $70 \%$ of students meet the criteria. But because it has not reached $85 \%$ completeness then continued with the second cycle. In the second cycle, $90 \%$ of students who met the criteria of mathematical problem-solving ability were obtained. The conclusion of this study is an increase in students' mathematical problem-solving abilities from cycle I to cycle II.
\end{abstract}

Historis Artikel:

Diterima: 3 Maret 2020

Direvisi: 10 Maret 2020

Disetujui: 29 Maret 2020

\section{Keywords:}

Cooperative learning, STAD, mathematical problem solving ability

Sitasi: Fatimah, A. E. (2020). Upaya peningkatan kemampuan pemecahan masalah matematis siswa MTs melalui model pembelajaran kooperatif tipe STAD. Journal of Didactic Mathematics, 1(1), $33-40$. https://doi.org/10.34007/jdm.v1i1.156

\section{PENDAHULUAN}

Pendidikan merupakan salah satu sarana yang digunakan dalam mengembangkan potensi diri siswa sehingga menjadi manusia yang lebih berkualitas dan lebih siap dalam menghadapi masalah dan tantangan dari perkembangan zaman. Dalam mensukseskan pendidikan, Komisi tentang Pendidikan Abad ke-21 (Commission on Education for the "21" Century), merekomendasikan empat strategi, yaitu: (1) Learning to learn, yaitu memuat bagaimana siswa mampu menggali informasi yang ada disekitarnya dari ledakan informasi itu sendiri; (2) Learning to be, yaitu siswa diharapkan mampu untuk mengenali dirinya sendiri, serta mampu beradaptasi dengan lingkungannya; (3) Learning to do, yaitu berupa tindakan atau aksi, untuk memunculkan ide yang berkaitan dengan sainstek; (4) Learning to live together, yaitu memuat bagaimana kita hidup dalam masyarakat yang saling bergantung antara satu dengan yang lain, sehingga mampu bersaing secara sehat dan bekerja sama serta mampu untuk menghargai orang lain (Trianto, 2010).

Pendidikan dapat diberikan kepada siswa salah satunya melalui pembelajaran yang dilakukan di sekolah. Rusman (2011:3) menyatakan bahwa, "Pembelajaran adalah proses interaksi peserta didik dengan guru dan sumber belajar pada suatu lingkungan belajar. Proses pembelajaran perlu direncanakan, dilaksanakan, dinilai, dan diawasi agar terlaksana secara efektif dan efisien." Melalui pembelajaran di sekolah, siswa diharapkan mampu mengaitkan setiap konsep yang dipelajarinya dengan konsep-konsep lain yang relevan sehingga terbentuk proses berpikir yang komprehensif 
secara utuh dan siswa belajar memecahkan masalah sebagai latihan untuk membiasakan belajar dengan tingkat kognitif yang tinggi. Pembelajaran yang mendukung hal ini salah satunya adalah pembelajaran matematika.

Matematika merupakan salah satu disiplin ilmu yang mendukung perkembangan ilmu pengetahuan dan teknologi karena matematika merupakan ilmu dasar yang dibutuhkan oleh semua ilmu pengetahuan untuk mendapatkan kemajuan yang berarti. Ruseffendi (1991:206) menyatakan bahwa, "Tujuan kurikuler pengajaran matematika SMP dan SMA dalam bidang pengetahuan adalah siswa memiliki pengertian dan pengetahuan matematika baik untuk menghadapi studi lebih lanjut, maupun untuk pemakaian praktis dalam mata pelajaran lain, dan dalam kehidupan seharihari." Mengingat pentingnya peranan matematika, maka sepantasnya pembelajaran matematika harus lebih diperhatikan dan ditingkatkan untuk mengembangkan kemampuan pemecahan masalah dalam kehidupan sehari-hari.

NCTM (National Council of Teacher of Mathematics, 2000:3) menyatakan bahwa, "Teachers help students make, refine, and explore conjectures on the basis of evidence and use a variety of reasoning and proof techniques to confirm or disprove those conjectures. Students are flexible and resourceful problem solvers." Dari pernyataan tersebut dapat dilihat bahwa seorang guru harus mampu mengubah siswa menjadi seorang pemecah masalah yang fleksibel dan cerdas. Sehingga tidak bisa dipungkiri lagi bahwa kemampuan pemecahan masalah menjadi fokus pembelajaran matematika di semua jenjang pendidikan. Selanjutnya Anderson (2009) mengemukakan "problem solving is recognized as an important life skill involving a range of processes including analyzing, interpreting, reasoning, predicting, evaluating and reflecting. Dengan kata lain, penekanan pada kemampuan pemecahan masalah dijadikan suatu keharusan dalam proses belajar mengajar. Dalam kehidupan sehari-hari dan ditempat kerja, menjadi seorang pemecah masalah yang baik dapat mendapatkan keuntungan besar, sehingga pemecahan masalah merupakan bagian integral dan tidak boleh terlepas dari pembelajaran pembelajaran matematika.

Pada mata pelajaran matematika, pemecahan masalah dapat berupa soal tidak rutin, yaitu soal yang dalam proses penyelesaiannya belum memiliki prosedur atau algoritma tertentu. Karena persoalannya merupakan masalah, maka penyelesaiannya merupakan pemecahan masalah.

Polya (1973:5) menyatakan bahwa: In order to group conveniently the questions and suggestions of our list, we shall distinguish four fases of the work. First, we have to understand the problem; we have to see clearly what is required. Second, we have to see how the various items are connected, how the unknown is linked to the data, in order to obtain the idea of the solution, to make a plan. Third, we carry out our plan. Fourth, we look back at the completed solution, we review and discuss it.

Adapun makna pernyataan Polya tersebut adalah dalam menyelesaikan soal pemecahan masalah memuat empat langkah fase penyelesaian, yaitu: (1) memahami masalah; (2) merencanakan penyelesaian; (3) menyelesaikan masalah sesuai rencana; (4) melakukan pengecekan kembali terhadap semua langkah yang telah dikerjakan. Meningkatkan lemampuan pemecahan masalah matematis mendorong siswa untuk mendekati masalah dalam dunia nyata dengan cara sistematis. Jika seorang siswa telah berlatih menyelesaikan masalah, maka dalam kehidupan nyata, siswa akan belajar mengorganisasikan kemampuannya dalam menyusun strategi yang sesuai dan mampu mengambil keprutusan untuk menyelesaikan sebuah masalah, sebab siswa tersebut mempunyai keterampilan mengumpulkan informasi yang relevan, menganalisis informasi dan menyadari betapa perlunya mengecek kembali hasil yang diperoleh.

Berdasarkan hasil observasi dan wawancara yang diperoleh dari MTs Islamiyah Medan, persentase nilai kemampuan pemecahan masalah matematis siswa masih rendah, hanya mencapai $52 \%$, sementara sekolah tersebut menetapkan nilai KKM untuk mata pelajaran matematika sebesar 75. Ini berarti masih banyak siswa yang belum tuntas belajar dalam matematika. Rendahnya kemampuan pemecahan masalah matematis siswa MTs Islamiyah Medan tersebut mungkin bisa terjadi karena model pembelajaran yang digunakan guru kurang cocok atau terlalu monoton sehingga kurang memotivasi siswa dalam belajar matematika yang akibatnya siswa kurang mampu dalam memecahkan masalah. Untuk mengatasi permasalahan tersebut, maka perlu diterapkan 
suatu model pembelajaran yang dapat meningkatkan minat dan motivasi belajar matematika, sehingga kemampuan pemecahan masalah matematis pada siswa menjadi meningkat. Salah satu alternatif pembelajaran yang dapat digunakan adalah model pembelajaran kooperatif tipe STAD.

Pembelajaran kooperatif memberikan siswa kesempatan berdiskusi untuk memperoleh jawaban yang disepakati bersama. Arends (2008:6) menyatakan bahwa lingkungan belajar kooperatif ditandai oleh proses yang demokratis dan peran aktif siswa dalam memutuskan segala yang dipelajari dan bagaimana caranya. Dengan kata lain, pembelajaran kooperatif merupakan pengajaran yang menggunakan struktur tujuan dan tugas yang mengharuskan siswa mengerjakan bersama-sama di dalam kelompok kecil serta bersama-sama saling mendukung untuk berhasil. Pembelajaran kooperatif yang digunakan adalah tipe Student Team Achievement Division (STAD), tipe STAD ini merupakan salah satu tipe kooperatif yang lebih menekankan pada adanya interaksi antar siswa dimana siswa saling memotivasi dan saling membantu dalam menguasi materi pelajaran guna mencapai prestasi yang maksimal (Isjoni, 2010:74). Melalui aktivitas kelompok, pembelajaran ini sangat cocok digunakan untuk meningkatkan kerjasama dan hubungan positif antar siswa, mengembangkan rasa percaya diri, serta meningkatkan kemampuan pemecahan masalah.

Pembelajaran kooperatif tipe Student Teams Achievement Divisions (STAD) terdiri atas lima komponen utama yaitu presentasi kelas, tim, kuis, skor kemajuan individual, rekognisi tim (Slavin, 2009:143). Pada presentasi kelas, guru memulai dengan menyampaikan indikator yang harus di capai. Pada presentasi kelas haruslah berfokus pada unit STAD. Dengan cara ini, para siswa akan menyadari bahwa mereka harus memberi perhatian penuh selama presentasi kelas, karena dengan demikian akan sangat membantu mereka mengerjakan kuis dan skor kuis tersebut menentukan skor tim mereka.

Berdasarkan uraian di atas, maka fokus penelitian ini adalah upaya peningkatan kemampuan pemecahan masalah matematis siswa MTs Islamiyah Medan melalui model pembelajaran kooperatif tipe STAD.

\section{METODE}

Penelitian ini merupakan Penelitian Tindakan Kelas (PTK). Penelitian yang dilakukan adalah penelitian kualitatif karena penelitian ini bertujuan untuk menjelaskan upaya-upaya yang dilakukan untuk meningkatkan kemampuan pemecahan masalah matematis siswa dan kendalanya dalam proses pembelajaran. Penelitian ini dilakukan di MTs Islamiyah Medan. Subjek penelitian ini adalah siswa kelas VII-1 Mts Islamiyah Medan yang terdiri dari 40 siswa, sedangkan objek penelitiannya adalah meningkatkan kemampuan pemecahan masalah matematis siswa menggunakan pembelajaran kooperatif tipe STAD pada pokok bahasan bangun datar segi empat. Tujuan penelitian ini adalah untuk meningkatkan kemampuan pemecahan masalah matematis siswa dan untuk mengetahui kesulitan-kesulitan apa saja yang dihadapi oleh siswa dalam mengerjakan soal pada pokok bahasan bangun datar segi empat.

Prosedur penelitian ini dimulai dengan perencanaan yang meliputi penentuan materi ajar yaitu bangundatar segi empat dengan pembelajaran kooperatif tipe STAD, penggandaan LAS dan penyusunan instrumen penelitian. Tindakan atau pelaksanaan penelitian berupa kegiatan pembelajaran yang mengimplementasikan model pembelajaran kooperatif tipe STAD pada pokok bahasan bangun datar segi empat di kelas VII-1 MTs Islamiyah Medan. Secara rinci prosedur pelaksanaan PTK menurut Hopkins adalah seperti Gambar 1 berikut: 


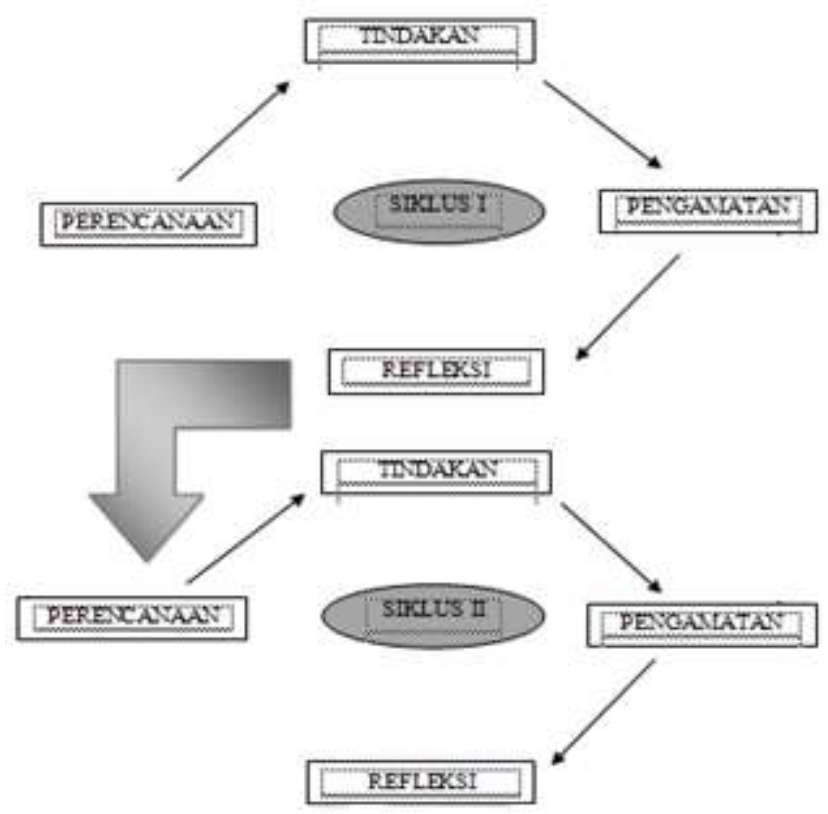

Gambar 1. Bagan PTK Model Kemmis dan Mc Taggart (Arikunto, 2006)

Instrumen yang digunakan dalam pengumpulan data penelitian ini adalah tes kemampuan pemecahan masalah matematis siswa berbentuk essay, observasi, dan wawancara. Untuk teknik analisis data, data dianalisis secara deskriptif dengan menggunakan teknik persentasi untuk melihat kecenderungan yang terjadi dalam kegiatan pembelajaran. Ada beberap rumus yang digunaka dalam penelitian ini, yaitu:

1. Menganalisis Hasil Observasi

Perhitungan observasi aktivitas siswa dan guru menggunakan rumus persentase menurut Sudijono (2009:43) sebagai berikut:

Persentase $(\%)=\frac{f}{N} \times 100 \%$

Keterangan:

$\mathrm{f}=$ jumlah skor siswa

$\mathrm{N}=$ jumlah siswa

2. Ketuntasan Belajar Siswa

Ada dua kategori ketuntasan belajar yaitu secara perorangan dan klasikal. Berdasarkan petunjuk pelaksanaan belajar mengajar kurikulum 1994 (Depdikbud, 1994), yaitu seorang siswa telah tuntas belajar apabila telah mencapai skor $65 \%$ atau nilai 65 , dan kelas disebut tuntas belajar apabila kelas tersebut terdapat $85 \%$ yang telah mencapai daya serap lebih dari atau sama dengan $65 \%$. Untuk menghitung persentase ketuntasan belajar digunakan rumus sebagai berikut:

$P=\frac{\sum \text { siswa tuntas belajar }}{\sum \text { siswa }} \times 100 \% \quad$ (Arikunto, 2001)

Pada akhir tiap siklus, peneliti akan menganalisis data yang diperoleh dari hasil observasi, wawancara dan tes kemampuan peecahan masalah. Hal ini akan dijadikan dasar untuk melanjutkan siklus atau tidak. Kriteria keberhasilan penelitian ini adalah jika ketuntasan belajar klasikalnya mencapai $85 \%$ siswa yang memperoleh nilai $\geq 65 \%$. Tetapi bila kriteria keberhasilan ini belum tecapai maka pengajaran yang dilaksanakan peneliti belum berhasil dan akan dilanjutkan ke siklus berikutnya. Dari hasil tes dapat diketahui peningkatan kemampuan pemecahan masalah matematika siswa melalui pembelajaran kooperatif tipe STAD dengan melihat pada pokok bahasan petunjuk pelaksanaan proses belajar mengajar.Untuk mengetahui tingkat kemampuan pemecahan masalah siswa yang diperoleh dari tes akhir digunakan rumus (Arikunto, 2006:237):

$$
T K P M=\frac{S P}{S T} X 100 \%
$$




\section{Keterangan:}

TKPM : Tingkat Kemampuan Pemecahan Masalah Matematika Siswa.

SP : Skor yang diperoleh siswa.

ST : Skor Total

Dengan kriteria Tingkat Kemampuan Pemecahan Masalah (TKPM) sebagai berikut:

$\begin{array}{ll}90 \%-100 \% & : \text { TKPM sangat tinggi } \\ 80 \%-89 \% & : \text { TKPM tinggi } \\ 65 \%-79 \% & : \text { TKPM sedang } \\ 55 \%-64 \% & : \text { TKPM rendah } \\ 0 \%-54 \% & : \text { TKPM sangat rendah }\end{array}$

Dengan demikian yang menjadi indikator keberhasilan dalam penelitian ini adalah peningkatan kemampuan pemecahan masalah matematis siswa yang dilihat dari hasil tes dan hasil observasi pada setiap siklus.

\section{HASIL DAN PEMBAHASAN}

Objek pada penelitian ini adalah meningkatkan kemampuan pemecahan masalah matematis siswa menggunakan pembelajaran kooperatif tipe STAD pada pokok bahasan bangun datar segi empat di kelas VII-1 MTs Islamiyah Medan. Penelitian ini dilakukan sebanyak dua siklus.

Hasil Penelitian Siklus I

Berdasarkan hasil observasi, wawancara dan data yang diperoleh dari tes kemampuan pemecahan masalah matematis I, berikut ini diuraikan kegagalan dan keberhasilan dalam pelaksanaan tindakan pada siklus I, yaitu: 1) Pengelompokan siswa berdasarkan penyebaran kemampuan siswa yang heterogen kurang efektif karena masih ada siswa yang tidak aktif dalam diskusi; 2) Ada beberapa kelompok yang belum mampu memecahkan permasalahan pada LAS I; 3) Perwakilan kelompok yang maju untuk mempresentasikan hasil kerja kelompoknya masih belum terampil dan kurang percaya diri dalam menyajikan hasil diskusi kelompoknya di depan kelas; 4) Kelompok siswa yang tidak maju presentasi juga masih kurang aktif dalam memberikan tanggapan kepada kelompok yang maju, sehingga guru masih perlu memberikan motivasi kepada siswa agar aktif dalam diskusi; dan 5) Kemampuan pemecahan masalah matematis siswa masih rendah. Adapun hasil tes kemampuan pemecahan masalah matematis siswa pada Siklus I dapat dilihat pada Tabel 1 berikut:

Tabel 1. Deskripsi Tingkat Kemampuan Pemecahan Masalah Matematis Siswa Siklus I

\begin{tabular}{|c|c|c|c|c|}
\hline $\begin{array}{l}\text { Persentase } \\
\text { Penguasaan }\end{array}$ & $\begin{array}{c}\text { Tingkat } \\
\text { Kemampuan }\end{array}$ & $\begin{array}{c}\text { Banyak } \\
\text { Siswa }\end{array}$ & $\begin{array}{c}\text { Persentase } \\
\text { Jumlah Siswa }\end{array}$ & $\begin{array}{l}\text { Rata-rata Skor } \\
\text { Kemampuan }\end{array}$ \\
\hline $90 \%-100 \%$ & Sangat tinggi & 5 & $12,5 \%$ & \multirow{5}{*}{$\begin{array}{c}78,5 \\
(70 \%)\end{array}$} \\
\hline $80 \%-89 \%$ & Tinggi & 15 & $37,5 \%$ & \\
\hline $65 \%-79 \%$ & Sedang & 8 & $20 \%$ & \\
\hline $55 \%-64 \%$ & Rendah & 12 & $30 \%$ & \\
\hline $0 \%-54 \%$ & Sangat rendah & - & - & \\
\hline & & 40 & $100 \%$ & \\
\hline
\end{tabular}

Tabel 1 menunjukkan peningkatan kemampuan pemecahan masalah matematis siswa dalam menyelesaikan soal-soal bangun datar segi empat setelah diterapkannya pembelajaran koperatif tipe STAD selama proses belajar mengajar berlangsung. Jumlah siswa yang telah mencapai ketuntasan belajar sebanyak 28 orang $(70 \%)$ dengan peningkatan ketuntasan belajar siswa mengalami kenaikan dengan rata-rata kelas mencapai 78,5. Karena kemampuan pemecahan masalah matematis siswa belum mencapai target minimal kemampuan pemecahan masalah yaitu $85 \%$ dari siswa yang mengikuti test mencapai nilai minimal 65 , maka perlu perbaikan program pengajaran sehingga tercapai target minimal penelitian. Karena ditemukan banyak kekurangan dalam pembelajaran 
selama siklus I dilaksanakan maka perlu dilakukan perbaikan tindakan. Oleh karena itu, penelitian dilanjutkan ke siklus II.

\section{Hasil Penelitian Siklus II}

Adapun hasil tes kemampuan pemecahan masalah matematis siswa pada Siklus II dapat dilihat pada Tabel 2 berikut:

Tabel 2. Deskripsi Tingkat Kemampuan Pemecahan Masalah Matematis Siswa Siklus II

\begin{tabular}{ccccc}
\hline $\begin{array}{c}\text { Persentase } \\
\text { Penguasaan }\end{array}$ & $\begin{array}{c}\text { Tingkat } \\
\text { Kemampuan }\end{array}$ & Banyak Siswa & $\begin{array}{c}\text { Persentase Jumlah } \\
\text { Siswa }\end{array}$ & $\begin{array}{c}\text { Rata-rata Skor } \\
\text { Kemampuan }\end{array}$ \\
\hline $90 \%-100 \%$ & Sangat tinggi & 11 & $27,5 \%$ & \\
\cline { 1 - 3 } $80 \%-89 \%$ & Tinggi & 20 & $50 \%$ & 84,3 \\
\hline $65 \%-79 \%$ & Sedang & 5 & $12,5 \%$ & $(90 \%)$ \\
\cline { 1 - 3 } $55 \%-64 \%$ & Rendah & 4 & $10 \%$ & \\
\cline { 1 - 4 } $0 \%-54 \%$ & Sangat rendah & - & - & \\
\hline \multicolumn{2}{c}{$\Sigma$} & 40 & $100 \%$ & \\
\hline
\end{tabular}

Kemampuan pemecahan masalah matematis siswa pada siklus II mengalami peningkatan yang cukup baik dari siklus I. Banyak siswa yang mencapai ketuntasan belajar pada siklus II yang mencapai ketuntasan belajar (dengan tingkat kemampuan memecahkan masalah sedang, tinggi, dan sangat tinggi) mencapai 36 siswa dengan persentase $90 \%$. Peningkatan kemampuan pemecahan masalah matematis siswa sudah mencapai target penelitian yaitu minimal $85 \%$ dari siswa yang mengikuti tes sudah mencapai ketuntasan belajar.

Berdasarkan deskriptif data dan analisa data, maka diperoleh temuan penelitian sebagai berikut: 1) Melalui model pembelajaran kooperatif tipe STAD dengan menggunakan LAS lebih efektif dalam meningkatkan kemampuan pemecahan masalah matematis siswa; 2) Pembagian kelompok secara heterogen dapat memberikan hasil yang maksimal dalam mengoptimalkan kemampuan anak dalam berdiskusi, sehingga pembagian kelompok berdasarkan teman sejawat memungkinkan siswa dapat bekerjasama dengan baik dalam menyelesaikan masalah; dan 3) Adapun letak kesalahan beberapa siswa dalam menyelesaikan soal cerita bangun datar segi empat adalah (1) siswa masih kurang mampu memahami soal cerita, (2) siswa masih mengalami kesulitan dalam mengubah soal cerita kedalam model matematika, (3) siswa masih mengalami kesulitan dalam menggunakan rumus, (4) siswa masih mengalami kesulitan dalam mengubah satuan hitung.

Penggunaan model pembelajaran kooperatif tipe STAD dalam upaya meningkatkan kemampuan pemecahan masalah matematis siswa ditandai dengan meningkatnya hasil tes kemampuan pemecahan masalah siswa. Ketika siklus I dilakukan, terjadi peningkatan kemampuan pemecahan masalah matematis siswa. Dari pemberian tes awal diperoleh peningkatan kemampuan pemecahan masalah siswa dalam menyelesaikan soal-soal bangun datar segi empat sebesar 52,5\% yakni dari 17,5\% menjadi 70\%. Hasil tes kemampuan pemecahan masalah matematis I diperoleh 28 siswa dari 40 siswa $(70 \%)$ telah mencapai ketuntasan belajar klasikal (nilai $\geq 65$ ) sedangkan 12 siswa lainnya (30\%) belum tuntas. Nilai rata-rata kelas yang diperoleh 78,5.

Setelah siklus II dilakukan, terjadi peningkatan kemampuan pemecahan masalah matematis siswa. Dari pemberian tes kemampuan pemecahan masalah matematis II diperoleh bahwa kemampuan pemecahan masalah matematis siswa mengalami peningkatan ketuntasan belajar sebesar $20 \%$ yakni dari $70 \%$ menjadi $90 \%$. Nilai rata-rata kelas yang diperoleh adalah 84,3 . Hasil selengkapnya dapat dilihat pada Tabel 3 berikut: 
Upaya peningkatan kemampuan pemecahan masalah matematis siswa...

Tabel 3. Deskripsi Tingkat Kemampuan Pemecahan Masalah Siswa Setiap Siklus

\begin{tabular}{ccccc} 
Persentase Penguasaan & Tingkat Kemampuan & Tes Awal & Siklus I & Siklus II \\
\hline $90 \%-100 \%$ & Sangat tinggi & 2 & 5 & 11 \\
\hline $80 \%-89 \%$ & Tinggi & - & 15 & 20 \\
\hline $65 \%-79 \%$ & Sedang & 5 & 8 & 5 \\
\hline $55 \%-64 \%$ & Rendah & 1 & 12 & 14 \\
\hline $5 \%-54 \%$ & Sangat rendah & 32 & - & - \\
\hline$\Sigma$ & & 40 & 40 & 40 \\
\hline Persentase ketuntasan klasikal & & $17,5 \%$ & $70 \%$ & $90 \%$ \\
\hline Persentase yang tidak tuntas & & $82,5 \%$ & $30 \%$ & $10 \%$
\end{tabular}

Adanya peningkatan dari siklus I ke siklus II tidak terlepas dari upaya-upaya yang dilakukan peneliti, yaitu membuat kelompok belajar siswa dengan kemampuan yang heterogen dan dengan kelompok yang berbeda antara siklus I dengan siklus II. Dengan cara ini siswa lebih aktif dalam pembelajaran dan lebih mudah dalam memahami pembelajaran karena yang membantu mereka jika mengalami kesulitan adalah teman sekelompok mereka yang sudah mengerti. Model belajar kooperatif tipe STAD juga mampu mengarahkan siswa untuk menggali pengetahuan yang dimilikinya untuk membuat suatu model matematis, menyusun rencana pemecahan, memonitor proses berfikir dalam pemecahan masalah dan mengevaluasi proses dan hasil pemecahan masalah. Pemecahan masalah yang dilakukan dalam kelompok kooperatif memiliki manfaat untuk mendiskusikan jawaban yang mereka peroleh kepada teman-temannya. Karakteristik dari pembelajaran kooperatif tipe STAD adalah pembelajaran yang mengharuskan siswa bekerja secara bersama-sama di dalam kelompok dan saling mendukung untuk berhasil. Pembelajaran STAD ini merupakan pembelajaran yang mengkombinasikan belajar individu dan kelompok selama kegiatan belajar mengajar berlangsung untuk mengatasi masalah-masalah matematis sehingga kemampuan pemecahan masalah matematis siswa dapat meningkat. Hal ini sejalan dengan penelitian (Siregar, 2019) bahwa langkah-langkah pembelajaran kooperatif tipe STAD dapat membantu siswa untuk meningkatkan kemampuan pemecahan masalahnya.

\section{KESIMPULAN}

Berdasarkan hasil penelitian diperoleh kesimpulan sebagai berikut: 1) Model pembelajaran kooperatif tipe Student Teams Achievement Divisions (STAD) dapat meningkatkan kemampuan pemecahan masalah matematis siswa pada pokok bahasan bangun datar segi empat, dan 2) Kemampuan pemecahan masalah matematis siswa mengalami peningkatan. Berdasarkan hasil tes kemampuan awal pemecahan masalah terdapat 7 siswa yang memiliki ketuntasan belajar, dengan persentase $17,5 \%$. Setelah pemberian tindakan dengan pembelajaran kooperatif tipe STAD, diperoleh jumlah siswa yang telah mencapai kriteria kemampuan pemecahan masalah sebanyak 28 orang, dengan persentase $70 \%$. Hal ini berarti terjadi peningkatan kemampuan pemecahan masalah hingga 52,5\%. Kemudian setelah diberikan tindakan II pada siklus II, jumlah siswa yang telah mencapai kriteria kemampuan pemecahan masalah sebanyak 36 orang, dengan persentase sebesar $90 \%$, ini berarti kemampuan pemecahan masalah matematis siswa mengalami peningkatan sebesar $20 \%$ dari siklus I.

\section{DAFTAR PUSTAKA}

Anderson, J. 2009. Mathematics Curiculum Development and the Role of Problem Solving. In ACSA Conference.

Arends, R. I. (2008). Learning to teach. Yogyakarta: Pustaka Pelajar.

Arikunto, S. (2001). Dasar-dasar evaluasi pendidikan. Jakarta: P'T. Bumi Aksara.

Arikunto, S. (2006. Penelitian tindakan kelas. Jakarta: PT. Bumi Aksara

Depdikbud. 1994. Kurikulum pendidikan dasar (GBPP). Jakarta: Depdikbud. 
Isjoni. (2010). Pembelajaran kooperatif: Meningkatkan kecerdasan komunikasi antar peserta didik. Yogyakarta: Pustaka Belajar.

NCTM. (2000). Principle and Standarts of School Mathematics. Reston VA: NCTM

Polya, G. (1973). How to slove it: A new aspect of mathematics method. New Jersey. Princeton University Press.

Ruseffendi, E. T. (1991). Pengantar kepada membantu guru mengembangkan kompetensinya dalam mengajar matematika untuk meningkatkan CBSA. Bandung: Tarsito.

Rusman. (2011). Model-model pembelajaran: Mengembangkan profesionalisme guru. Jakarta: RajaGrafindo Persada.

Siregar, T. J. (2019). Pengaruh pembelajaran kooperatif tipe STAD terhadap peningkatan kemampuan pemecahan masalah matematis siswa SMP. AXIOM: Jurnal Pendidikan dan Matematika, 8(2), 203-213. tp://dx.doi.org/10.30821/axiom.v8i2.6341

Slavin, R. E. (2005). Cooperative learning: Theory, research and practice. London: Allymand Bacon.

Sudijono, A. (2011). Pengantar evaluasi pendidikan. Jakarta: PT. Raja Grafindo Persada.

Trianto. 2010. Mendesain model pembelajaran inovatif-progresif. Jakarta: Kencana Prenada Media Group. 